\title{
«ПРОТИВОРАКЕТНОСТЬ» В РОССИЙСКО-АМЕРИКАНСКИХ ОТНОШЕНИЯХ
}

\author{
Lilly, Bilyana. Russian Foreign Policy towand Missile Defense: \\ Actors, Motivations, and Influence. London: Lexington Books, \\ 2๑4. $390 \mathrm{p}$.
}

\begin{abstract}
ЛилЛИ, Биляна. Внешняя политика России в области противоракетной обороны: ИгрокИ, мотивы и влияние. Лондон: Из-во «Лексингтон Букс», 2014. 390 с.
\end{abstract}

Проблематика противоракетной обороны (ПРО) больше тридцати лет служит одним из главных источников российскоамериканских противоречий. С того момента, как президент Рейган объявил о запуске программы Стратегической оборонной инициативы в 1983 году, отношения Москвы и Вашнгтона пережили несколько периодов обострений, в центре которых были именно вопросы ПРО.

Особенную актуальность эти вопросы приобрели с выходом США из Договора по ПРО в 2001-2002 годах. Администрация Дж. Буша-мл. таким образом завершила процесс изменения стратегического подхода США к вопросам противоракетной обороны, результатом чего стал окончательный отказ Вашингтона от соблюдения каких-либо международных ограничений при реализации соответствующих программ. Новая позиция США, в свою очередь, вызвала рост озабоченности Москвы относительно планов по дальнейшему развитию такой программы. Эта озабоченность, резко усилившаяся после оглашения планов по «созданию третьего позиционного района» ПРО в Восточной Европе в 2006 году, вынудила Кремль выдвинуть компромисс по ПРО в качестве условия для продолжения переговоров по контролю над вооружениями. В дальнейшем именно планы по размещению элементов американской системы в Европе превратились в центральный предмет российскоамериканских разногласий в рамках проблемы ПРО в целом.

В период «перезагрузки» российско-американских отношений при администрации Б. Обамы часть противоречий между Белым домом и Кремлем удалось сгладить, однако ключевые спорные вопросы решены не были. Наиболее характерно эти противоречия выразились в разночтениях, возникших в процессе ратификации договора по сокращению наступательных вооружений (CHB) на рубеже 2010-2011 годов. Так, Сенат США в своей ратификационной грамоте зафиксировал положение о том, что новый договор не накладывает каких-либо ограничений на развертывание систем ПРО. Федеральное Собрание Российской Федерации, в свою очередь, при принятии закона о ратификации СНВ обозначило развертывание системы противоракетной обороны в качестве основания для выхода из договора.

С тех пор российско-американские противоречия лишь усугублялись. Очередной виток разногласий не за горами - на текущий год намечено развертывание базы американских противоракет SM-3 Block IB в Румынии, а кризис на Украине вызвал целую волну спекуляций относительно возможностей дальнейшего наращивания и расширения системы ПРО в Европе. 
При всей важности проблемы для российско-американских отношений, она, в отличие, к примеру, от вопросов ядерной политики, не привлекает большого внимания исследователей. Как российское, так и американское сообщество экспертов в области ПРО ограничены и замкнуты: за последние десять лет в этой области практически не появилось новых имен, а серьезные открытые исследования по данной проблематике можно пересчитать по пальцам.

В этой связи сложно переоценить актуальность новой книги болгарского исследователя Б. Лилли, в настоящее время являющейся сотрудником Брукингского института. «Внешняя политика России в области противоракетной обороны: игроки, мотивы и влияние» является первой монографией, представляющей собой комплексный анализ российской политики в области ПРО.

Центральное место в монографии Лилли занимает гипотеза о том, что «российские возражения против создания системы ПРО США в Европе, в отличие от официальной позиции Москвы при Путине, обусловлены не только соображениями безопасности» (с. 327). Согласно этой логике, современные российско-американские противоречия в области ПРО вышли за рамки разногласий относительно технических параметров системы из-за того, что Россия воспринимает проблему ПРО как «основу для более широких суждений о внешнеполитической легитимности [российской власти] и геополитическом положении [Москвы] среди мировых держав» (с. xxv).

По мнению автора, российская политика в области ПРО «обусловлена совокупностью политических факторов» (с. 98). В качестве ключевого аргумента в пользу своей гипотезы Лилли приводит характерную черту этой политики - ее непоследовательность, вызванную противоречием подходов, применяемых Россией при выстраивании диалога по ПРО с Западом. Автор отмечает, что, с одной стороны, Москва постоянно пытается привлечь Вашингтон и Брюссель к сотрудничеству в вопросах совместной борьбы с потенци- альными ракетными угрозами, а с другой выступает резко против развертывания элементов ПРО в Восточной Европе (с. 97).

Во второй главе Лилли подробно анализирует военные аспекты, связанные с развертыванием элементов ПРО в Европе. Автор неоднократно высказывается в пользу суждения о том, что военная угроза от развертывания ПРО в Европе преувеличена (c. 10, 81, 120, 274). Подвергая анализу ключевые аргументы Москвы против развертывания ЕвроПРО, она уделяет первоочередное внимание дискуссии о принципиальной возможности перехвата российских межконтинентальных баллистических ракет (МБР) средствами противоракетной обороны, расположенными в Европе. Автор делает однозначный вывод, о том, что планируемая конфигурация ЕвроПРО не представляют какой-либо угрозы для российского ядерного потенциала в силу технических характеристик существующих сил сдерживания, а также особенностей их дислокации. По оценкам Лилли, даже в случае наращивания потенциала системы ПРО, он может быть легко нейтрализован Россией, в том числе с использованием широкого арсенала мер противодействия, имеющегося у Москвы (с. 69).

Основываясь на данных анализа, автор делает вывод о том, что соображения военной безопасности не могут являться исключительным фактором, обосновывающим оппозицию Москвы процессу развертывания ПРО в Европе. В этой связи Лилли подчеркивает приоритет политических факторов. В качестве основополагающего воображения, влияющего на формирование политики Москвы по ПРО на современном этапе, обозначена стратегия России, направленная на восстановление и закрепление за собой статуса «великой державы», причем как в самосознании российского населения, так и в отношениях с третьими странами. По мнению Лилли, «прекращение действия Договора по ПРО позволило США и другим членам НАТО ... снизить самовосприятие России в качестве великой державы» и создало угрозу для российских амбиций (с. 25). Автор выделя- 
ет прямую взаимосвязь между развитием программ ПРО в Восточной Европе - peгионе, который является важной сферой геополитических интересов для Москвы, и возрождением России в желаемом статусе.

Идея о необходимости восстановления статуса великой державы имеет серьезную поддержку внутри страны. В первой главе Лилли приводит данные социологических опросов, свидетельствующих о высокой степени поддержки этой идеи среди российского населения, а также подтверждающих популярность «жесткой линии» Москвы при выстраивании отношений с Западом. Другие опросы показывают, что, начиная со второй половины 2000-х годов подавляющее число россиян считают размещение ПРО в Европе большей угрозой безопасности России, нежели ядерная программа Ирана и ядерное оружие КНДР. По мнению Лилли, «восприятие системы ПРО и стран Запада, создающих ее, в качестве угрозы для России, усиливает идею о том, что Россия живет в «кольце врагов», и ей нужен сильный лидер, способный принять необходимые меры для защиты государства», что в итоге приводит к увеличению популярности президента Путина среди российского населения (с. 32-33). На этих основаниях Лилли делает закономерный вывод о том, что развитие программ ПРО США и НАТО, с одной стороны, подрывает авторитет России как великой державы в глазах международного сообщества, а с другой, является эффективным консолидирующим инструментом применительно к внутренней политике.

В качестве другого немаловажного фактора российской оппозиции процессу создания ПРО в Европе Лилли называет исключение России из процесса ее создания, а также отсутствие возможности оказания влияния на этот процесс. По мнению автора, данный фактор противоречит российской концепции «многополярности», в соответствии с которой, Россия не может себе позволить остаться «за бортом» какоголибо существенного процесса в европейском регионе (с. 27). При этом нахождение России вне дискуссий по поводу разверты- вания ПРО в Европе сказывается на других международных вопросах, воспринимаемых Москвой как вызовы. В частности, на расширении НАТО за счет государств Центрально-Восточной Европы. Российское руководство воспринимает альянс как «агрессивный и экспансионистски настроенный реликт холодной войны, управляемый напрямую Вашингтоном» (с. 28). По мнению Лилли, такое отношение Москвы к НАТО сформировано под влиянием «глубоко укоренившегося традиционалистского подхода», превалирующего в российском руководстве (с. 217).

Авторская точка зрения о том, что российскую оппозицию развертыванию ЕвроПРО нужно воспринимать не столько как ответ на военную опасность, которую представляет и может представлять такая система, сколько как реакцию Москвы на целый ряд политических факторов глобального масштаба, видится справедливой и хорошо обоснованной. В то же время стоит отметить ряд недостатков, связанных с отражением особенностей этой концепции в книге.

Выдвигаемая Лилли гипотеза не является принципиально новой для экспертного сообщества. Многие специалисты как в России, так и в США разделяют тезис о том, что реакция Москвы на развертывание ПРО в Европе не была бы столь жесткой, если бы она базировалась только на существующих оценках военных угроз. В то же время комплексная попытка сформулировать и доказать гипотезу, в основе которой лежит данный тезис, предпринимается впервые.

Прибегая в своей монографии к проблемно-хронологическому методу рассмотрения российской политики в области ПРО после 2000 года, автор прослеживает логику формирования этой политики с учетом максимально возможного числа аспектов. Возможно, поэтому Лилли упускает из вида ключевую причину трансформации российской политики в области ПРО во второй половине $2000-х$. Так, несмотря на то что большая часть книги посвящена рассмотрению ключевого аспекта 
российско-американских разногласий: проблеме ПРО в Европе, автор не выделяет особую важность этой проблемы для отношений Москвы и Вашингтона. Лилли считает, что появление планов по размещению ПРО в Европе стоит в одном ряду с другими политическими факторами, в частности с появлением планов по принятию Украины и Грузии в НАТО. Несомненно, все эти шаги Вашингтона и Брюсселя также сыграли свою роль в охлаждении отношений по линии Россия-США и РоссияНАТО. Однако очевидно и то, что именно перспектива появления элементов ПРО в Восточной Европе заставила Россию заявить о возможности применения ответных мер не только политического, но и сугубо военного характера.

Авторская оценка угрозы развертывания ЕвроПРО для российских МБР, несмотря на ее фундированность, тем не менее довольно «проблематична». Лилли игнорирует фактор ПРО при нанесении ответного ядерного удара, когда существенная часть российских стратегических носителей уничтожена. В таком случае решение проблемы успешного перехвата оставшихся стратегических носителей станет на порядок легче, а влияние даже ограниченной ПРО на стратегическую стабильность изменится, на что неоднократно указывали ряд российских экспертов. Но эти частные замечания нисколько не снижают общего качества данного исследования.

Завершая рецензию, хотелось бы отдельно отметить то, что в своей работе Лилли использовала поистине огромное количество русскоязычных источников. При обосновании российской позиции по ПРО автор в большинстве случаев делает ссылку на документ или статью, написанную на русском языке. Столь кропотливая работа с источниками стала главной предпосылкой успеха данной книги. Хотелось бы, чтобы и другие зарубежные эксперты изучали российскую внешнюю политику в первую очередь по российским источникам, а не по тому, как она отражена в зарубежной прессе.

Александр Чеков 